\title{
Salinity-Growth Response and Ichthyotoxic Potency of the Chilean Pseudochattonella verruculosa
}

\author{
Jorge I. Mardones ${ }^{*}$, Gonzalo Fuenzalida ${ }^{1}$, Katherine Zenteno², \\ Catharina Alves-de-Souza ${ }^{3}$, Allisson Astuya ${ }^{4}$ and Juan José Dorantes-Aranda ${ }^{5}$
}

${ }^{1}$ Centro de Estudios de Algas Nocivas, Instituto de Fomento Pesquero, Puerto Montt, Chile, ${ }^{2}$ Facultad de Ciencias Biológicas, Pontificia Universidad Católica de Chile, Santiago, Chile, ${ }^{3}$ Algal Resources Collection, MARBIONC, Center for Marine Sciences, University of North Carolina Wilmington, Wilmington, NC, United States, ${ }^{4}$ Laboratorio de Cultivo Celular y Genómica Marina, Departamento de Oceanografía, Facultad de Ciencias Naturales y Oceanográficas y Centro de Investigación Oceanográfica COPAS Sur-Austral de la Universidad de Concepción, Concepción, Chile, ${ }^{5}$ Institute for Marine and Antarctic Studies, University of Tasmania, Hobart, TAS, Australia

\section{OPEN ACCESS}

Edited by:

Stelios Katsanevakis, University of the Aegean, Greece

Reviewed by:

Jose Luis Iriarte,

Universidad Austral de Chile, Chile

Sandra Lage,

Swedish University of Agricultural

Sciences, Sweden

*Correspondence:

Jorge I. Mardones jorge.mardones@ifop.cl

Specialty section: This article was submitted to Marine Ecosystem Ecology, a section of the journal Frontiers in Marine Science

Received: 02 August 2018 Accepted: 18 January 2019 Published: 07 February 2019

Citation:

Mardones Jl, Fuenzalida G, Zenteno K, Alves-de-Souza C, Astuya A and Dorantes-Aranda JJ (2019) Salinity-Growth Response and Ichthyotoxic Potency of the

Chilean Pseudochattonella verruculosa. Front. Mar. Sci. 6:24. doi: 10.3389/fmars.2019.00024
Despite salmon farmers suffering the worst damage from a harmful algal bloom in Chile's history (US\$800M) due to a massive outbreak of the dictyochophyte Pseudochattonella verruculosa in $2016\left(\sim 7000-20,000\right.$ cells $\left.\mathrm{ml}^{-1}\right)$, the effect of environmental drivers and the potency of lytic toxins produced by the local clones of this species remain still largely unexplored. Based on the drastic oceanographic anomalies observed in the Chilean fjords during the 2016-El Niño "Godzilla" event, the role of salinity (15 to 35 psu) on Pseudochattonella cell growth and cytotoxicity was studied by culturing, scanning electron microscopy (SEM) and using a rainbow trout cell line RTgill-W1 assay to define: (1) vegetative growth rates, (2) cell taxonomy, (3) ichthyotoxicity of monoclonal cultures at 25 and 35 psu in salinity, (4) differences in toxicity of lysed cells and supernatant at different cell concentrations (from 10 to 100,000 cells $\mathrm{ml}^{-1}$ ), and (5) temporal stability of lytic compounds. This study formally confirms the presence of $P$. verruculosa in Chilean waters using the large subunit (LSU) of the nuclear ribosomal RNA gene. The Chilean P. verruculosa ARC498 strain showed maximum cell densities at 30 psu (max.

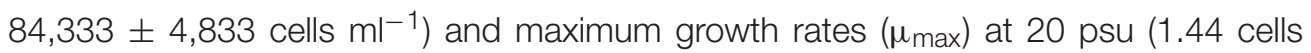
$\mathrm{d}^{-1}$ ). Cultures at 15 psu showed suppressed maximum cell density (max. $269 \pm 71$ cell $\mathrm{ml}^{-1}$ ) but high $\mu_{\max }$ were recorded at the beginning of the exponential growth (1.31 cells $\left.\mathrm{d}^{-1}\right)$. No significant differences were observed between lysed cells and supernatant treatments in the two salinity levels, suggesting that the most lytic portion is released into the cell-free media instead of remaining cell bound. Cytotoxicity was correlated to cell abundance, reducing gill cell viability down to 80 and $65 \%$ compared to controls at 10,000 and 100,000 cells $\mathrm{ml}^{-1}$, respectively. Unexpectedly, lytic compounds from $P$. verruculosa ARC498 at 35 psu showed to be less toxic than cultures at 25, where a noticeable presence of peripheral mucocysts were observed by SEM. Lytic compounds from in vitro experiments are weakly toxic even at high cell concentrations, highly unstable and rapidly degraded in the light after 5 days of storage at $15^{\circ} \mathrm{C}$. Our results point to the important effect of salinity on growth and ichthyotoxic potency of Pseudochattonella species and highlight the need for a deeper insight into the role of mucocysts in fish gill damage, which would provide a greater understanding as to the harmful modes of action of this species. 


\section{INTRODUCTION}

Harmful Algal Blooms (HABs) have become an important threat for coastal aquaculture in the last decades (Hallegraeff et al., 2017). The more severe harmful effects occur when some microalgae produce toxic secondary metabolites that display potent biological activity against a wide variety of marine organisms or in humans upon consumption of contaminated seafood (Skjelbred et al., 2011). Among the $\sim 80$ species described as having the capacity to produce toxins, flagellates are recognized as the most harmful group (Wright and Cembella, 1998; Hallegraeff, 2003).

The heterokont genus Pseudochattonella encompass marine ichthyotoxic phytoflagellates recently added to the list of fish killing microalgae (Eckford-Soper and Daugbjerg, 2016b). Originally described as Chattonella verruculosa (Raphidophyceae) by Hara et al. (1994), molecular genetic analysis later on erected a new genus and Pseudochattonella verruculosa (Y. Hara and Chihara) Hosoi-Tanabe, Honda, Fukaya, Otake, Inagaki and Sako, was transferred to the class Dictyochophyceae (Hosoi-Tanabe et al., 2007). Subsequently a second species, Pseudochattonella farcimen (Eikrem, Edvardsen, and Throndsen), was assigned to this genus (Edvardsen et al., 2007; Eikrem et al., 2009). Blooms of Pseudochattonella species have caused several fish kills in Northern Europe (Lu and Goebel, 2000; Naustvoll et al., 2002; Edvardsen et al., 2007; Riisberg and Edvardsen, 2008), Japan (Yamamoto and Tanaka, 1990; Baba et al., 1995; Imai et al., 1998), New Zealand (MacKenzie et al., 2011; Chang et al., 2014) and Chile (Mardones et al., 2012; Clément et al., 2016; León-Muñoz et al., 2018).

The first reported bloom of Pseudochattonella sp. in Chilean waters occurred on January of 2004 in the locality of Cholgo Los Lagos region (Mardones et al., 2012). Pseudochattonella sp. has since then been held responsible for several salmon mortality events in January and February of 2005, 2009, 2011, and in March 2016 (Mardones et al., 2012; Clément et al., 2016; LeónMuñoz et al., 2018). The last bloom was the more massive one, extending several $\mathrm{Km}^{2}$ in the inner zone of fjords and channels and causing the worst damage from HABs on Chilean salmon industry so far. Losses for the salmon industry in this occasion were calculated in 100,000 metric tons of Atlantic and Coho salmon and trout, equivalent to an export loss of US $\$ 800$ million (15\% of Chile's yearly production) (Clément et al., 2016). This massive salmon mortality event evidenced the high fish-killing potency of the Chilean Pseudochattonella species, however, its ichthyotoxic mechanism in not yet understood.

Research on Pseudochattonella spp. toxicity has proven to be difficult and has led to different opinions. Some studies have shown that cell culture extracts can produce a toxic effect on planktonic organisms and cell lines (Skjelbred et al., 2011; Chang et al., 2014), whereas studies conducted by Andersen et al. (2015) suggested that live cells are required to induce a toxic effect on fish. The latter hypothesis relates the toxicity of Pseudochattonella spp. to the presence of peripheral saccular extrusomes called "mucocysts" that give these algae their characteristic warty appearance. The ecological function of the mucocysts is not clear but it has been suggested their implication as a mechanism to capture bacteria (Jeong et al., 2010) or as grazer deterrents (Tillmann and Reckermann, 2002).

The Chilean fjords are characterized by freshwater inputs from precipitation and melt water from Patagonian ice fields, which results in strong haline vertical gradients creating a unique highly productive area (Rignot et al., 2003). These stratified systems act as a barrier against the vertical propagation of turbulence from adjacent high mixing layers allowing for vertically heterogeneous phytoplankton distributions (Stacey et al., 2007; Yamazaki et al., 2010). Horizontally extensive subsurface patches of phytoplankton, the so-called "thin layers," have been observed to persist from hours to weeks and can contain more than $75 \%$ of the total microalgae biomass in the water column (Holliday et al., 2003; Sullivan et al., 2010). Interestingly, key target HAB species in the northern Patagonian waters, such as Dinophysis spp. and the ichthyotoxic Pseudochattonella sp., have been observed in subsurface 'thin layers' (Alves-de-Souza et al., 2014; Clément et al., 2016). This fact points to the crucial role of salinity, as well as, nutrient availability and fluctuations in $p \mathrm{CO}_{2} / \mathrm{pH}$ for $\mathrm{HAB}$ formation in these highly heterogeneous estuarine systems.

The 2016 bloom seemed to be related to exceptional ocean and inshore water conditions in late 2015 due to a strong El Niño event and the positive phase of the Southern Annular Mode that altered the atmospheric circulation in the adjacent Pacific Ocean (León-Muñoz et al., 2018). The resultant increase in surface water temperature $\left(>15^{\circ} \mathrm{C}\right)$ and reduced freshwater input allowed the advection of more saline ( $\sim 33-35$ in salinity) and nutrient-rich offshore waters into the fjords. These changes toward relatively high salinity in the Reloncaví Sound (25-27 psu) were observed prior to the bloom in February. By mid-March there was an increase in salinity ( $>30 \mathrm{psu}$ ) and a gradual drop in temperature, probably associated to lower river streamflow, which could have stimulated the massive Pseudochattonella bloom (LeónMuñoz et al., 2018). The maximum cell concentrations during the event were estimated to be between 7,000 and 20,000 cells $\mathrm{ml}^{-1}$ (Clément et al., 2016; León-Muñoz et al., 2018), several orders of magnitude higher of those recorded in previous Pseudochattonella sp. blooms in the area (Mardones et al., 2012). It has been suggested that high salinity variations in estuarine systems can strongly alter microalgae composition (Kirst, 1990), therefore this variable could have played key role in the proliferation, as well as, ichthyotoxic potency of Pseudochattonella sp. in the 2016 bloom event. However, ecophysiological studies on Chilean strains have not been yet undertaken since cultures of this species were only established after 2016 (Paredes et al., 2016; this study).

The aim of this study was to officially confirm the taxonomic identification of the Chilean Pseudochattonella populations, as well as, to provide the first assessment of growth parameters of species of this genus under different salinity levels. The potential lytic activity of Pseudochattonella species was also tested in intraand extracellular metabolites using a fish gill cell line assay, as this has important implications for their mechanistic effects. 


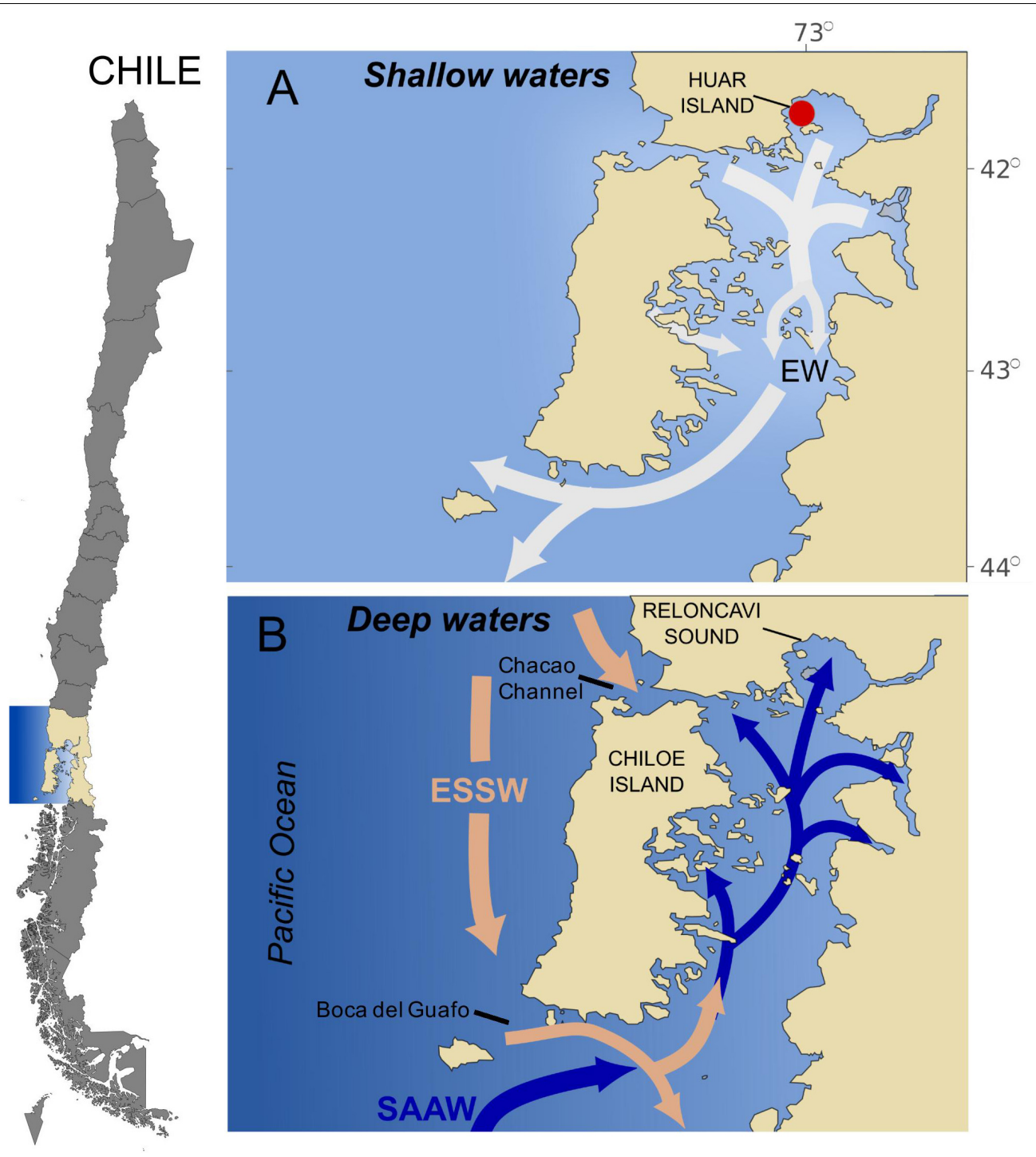

FIGURE 1 | Study area showing a schematic horizontal circulation model by layers (adapted from Silva et al., 1998). (A) Surface Estuarine Water EW (0- 30 m); (B) intermediate Subantarctic Water (SAAW) ( 30- 150 m) and deep Equatorial Subsurface Water (ESSW) ( 150 m to the bottom). The red circle shows the origin of the Pseudochattonella ARC 498 strain.

\section{MATERIALS AND METHODS}

\section{Study Area}

In the northern Patagonian fjords $\left(42-44^{\circ} \mathrm{S}\right)$, where Pseudochattonella sp. bloom events have been registered, the vertical distribution of water masses presents a three-layer structure. A surface layer of Estuarine Waters (EW) (EW-Marine 21 to 31 psu; EW-Brackish 11 to 21 psu and EW-Freshwater 2 to $11 \mathrm{psu}$ ) between 0 and $20-30 \mathrm{~m}$ moves offshore increasing its salinity compared to fresh water sources (Figure 1A). An intermediate layer of Sub-Antarctic Waters (SAAW 33 psu) between 30 and $150 \mathrm{~m}$ enters the inner part of the fjords from the south. The mix between EW and SAAW in the inner part of the fjords is called Modified Sub-Antarctic Waters (MSAAW). A deep layer of remnants of Equatorial Subsurface Waters
(ESSW > 33) from $150 \mathrm{~m}$ to the ocean bottom enters the inland sea of Chiloé through the Chacao channel and Boca del Guafo (Figure 1B; Silva et al., 1998). According to Castillo et al. (2016), the waters in the Reloncaví fjord are dominated along the seasons by EW in the upper layer and MSAAW in the deep layer.

\section{Culture Origin and Maintenance Algal Culturing}

A monoclonal culture of the toxic dictyochophyte Pseudochattonella verruculosa ARC498 strain was isolated from the Reloncaví sound during the 2016 bloom, kept in culture in the Algal Resources Collection at the University of North Carolina Wilmington and later transferred to the CREAN-IFOP laboratory to perform this study. Non-axenic cultures were grown in F/2 medium (Guillard and Ryther, 1962) at $15^{\circ} \mathrm{C}$ 
in sterile filtered $(0.22 \mu \mathrm{m})$ seawater $(25 \mathrm{psu})$ at $20 \mu \mathrm{mol}$ photon $\mathrm{m}^{-2} \mathrm{~s}^{-1}$ (cool white fluorescent lamps) under a 12:12 h light:dark cycle.

\section{Gill Cell Line}

The cell line RTgill-W1, originally cultured from gill filaments of rainbow trout Oncorhynchus mykiss (Bols et al., 1994), was acquired from the American Type Culture Collection (CRL-2523, ATCC). Cells were cultured at $17^{\circ} \mathrm{C}$ in the dark in Leibovitz's L-15 medium (L1518 Sigma), supplemented with 10\% (v/v) fetal bovine serum (FBS, 12003C, Sigma), and an antibioticantimycotic solution (A5955, Sigma) containing amphotericin B $\left(25 \mathrm{mg} \mathrm{ml}^{-1}\right)$, streptomycin $\left(10 \mathrm{mg} \mathrm{ml}^{-1}\right)$ and penicillin $(10,000$ units $\mathrm{ml}^{-1}$ ) in $25-\mathrm{cm}^{2}$ culture-treated flasks (3100-025, Iwaki). $0.25 \%$ trypsin-0.02\% EDTA in Hank's balanced salt solution (59428C, Sigma) was used to detach cells that grew as an adherent monolayer at the bottom of the flask. Subcultures were normally established twice per week at a ratio of 1:2 with L-15 medium renewal.

\section{Molecular Identification of $\boldsymbol{P}$. verruculosa}

Cells from monoclonal cultures of the ARC498 strain (GenBank accession number MK106355.1) were pelleted by centrifugation at $1500 \mathrm{~g}$ for $10 \mathrm{~min}$ at $4^{\circ} \mathrm{C}$, the supernatant discarded and the cell pellets incubated at $65^{\circ} \mathrm{C}$ for $3 \mathrm{~h}$ in $1 \mathrm{ml} \mathrm{CTB}$ buffer and $10 \mu \mathrm{l}$ Proteinase K $(10 \mathrm{mg} / \mathrm{ml})$. The LSU (D1-D3) region of the rDNA gene was amplified using the primers D1R and D2C (Scholin et al., 1994; Edvardsen et al., 2003) in a SimpliAmp ThermoCycler (Applied Biosystems). The PCR protocol was as follow: initial denaturation step of $95^{\circ} \mathrm{C}$ for $1 \mathrm{~min}$, followed by 35 cycles of $95^{\circ} \mathrm{C}$ for $30 \mathrm{~s}, 56^{\circ} \mathrm{C}$ for $30 \mathrm{~s}, 72^{\circ} \mathrm{C}$ for $30 \mathrm{~s}$, followed by a $7 \mathrm{~min}$ extension at $72^{\circ} \mathrm{C}$. PCR products were visualized on a $1.5 \%$ agarose gel and the product was purified using the Illustra GFX PCR DNA and gel band purification kit (GE Healthcare), and sequenced in both directions in Macrogen Korea. LSU rDNA sequences were aligned along with sequences available in GenBank using MUSCLE (Edgar, 2004), implemented in Geneious (Biomatters Ltd.). Unalienable regions were excluded from the LSU alignment. jModelTest (Posada, 2008) was used to identify appropriate models of sequence evolution (LSU: GTR + I), and maximum likelihood analyses were conducted using PhyML (Guindon et al., 2010). Support values were estimated using Likelihood Ratio Test (aLRT, Anisimova and Gascuel, 2006) and bootstrap analysis (1000 replicates). Bayesian analyses were conducted using MrBayes V3.1.2 (Ronquist and Huelsenbeck, 2003) using the appropriate model (GTR + I).

\section{Morphological Characteristics and Growth of $P$. verruculosa Cultures Scanning Electron Microscopy (SEM) of $P$. verruculosa}

Scanning electron microscopy analysis was performed following Botes et al. (2002). Briefly, a P. verruculosa culture was fixed 1:1 with $2 \%$ osmium tetroxide $\left(\mathrm{OsO}_{4}\right)$ made up with filtered seawater. The $1 \%$ solution of fixed cells and $\mathrm{OsO}_{4}$ was applied on coverslips coated with poly-L-lysine (P-4832, Sigma) and left for $\sim 30$ min for $P$. verruculosa cells attachment. Attached cells were washed by submerging the coverslips for $10 \mathrm{~min}$ in a 1:1 solution of distilled water and filtered seawater, followed for a 10-min wash in distilled water. The coverslips were then taken through a graded ethanol series $(30,50,70,80,90,95$, and 100\%, $10 \mathrm{~min}$ each step). Following removal from the $100 \%$ ethanol, few drops of hexamethyldisilazane (HMDS) were immediately added onto the coverslips to substitute critical point drying (CPD). Samples were coated with gold-palladium (60:40) and viewed with a JEOL JSM 6380LV SEM.

\section{Pseudochattonella verruculosa Growth}

Exponentially growing cultures of $P$. verruculosa ARC498 were acclimated to the target salinity treatments of $15,20,25,30$, and 35 psu for 3 weeks prior to the experiments (corresponding to 10 generations). Pre-acclimated cultures were inoculated into sterile $60 \mathrm{ml}$ polystyrene culture flasks containing $50 \mathrm{ml}$ of F/2 media adjusted to the target salinity conditions. All treatments were performed in three replicates with an initial cell density of 500 cells $\mathrm{ml}^{-1}$. The light intensity of $20 \mu \mathrm{mol}$ photon $\mathrm{m}^{-2}$ $\mathrm{s}^{-1}$ was chosen as it was considered the optimum saturation irradiance for the Chilean ARC498 P. verruculosa growth from pre-experimental measurements (data not shown). Thus, the growth rates obtained at the five salinity treatments correspond to maximum rates. The experiment was carried out for 27 days with samples taken every 3-7 days.

Cells concentration was determined immediately after sampling, based on buffered-Lugol's fixed cells quantified under an inverted light microscope (Olympus, CKX41) using a Sedgewick-Rafter chamber. In every sampling date, the mean cell number obtained from the three replicates was used to calculate the growth rate $\mu\left(\mathrm{d}^{-1}\right)$ :

$$
\mu=\frac{\ln \left(c_{1} / c_{0}\right)}{t_{1}-t_{0}}
$$

were $c_{o}$ and $c_{1}$ are the cell concentrations (cell $\mathrm{ml}^{-1}$ ) at the beginning $\left(t_{0}\right)$ and end $\left(t_{1}\right)$ of the incubation period (days), respectively. At the end of the experiment, all cultures were left for 15 days under the original experimental conditions to observe the behavior of multinucleated cell aggregations as described by Tomas et al. (2004). These cell aggregations are believed to serve as resting stages and can potentially release a huge number of daughter cells that could alter the in vitro estimation of growth rates due to a sudden cell increase.

\section{Pseudochattonella Cytotoxicity Against Fish Gill Cells}

The cytotoxicity assay with $P$. verruculosa ARC498 was carried out using conventional multiwell microplates according to Dorantes-Aranda et al. (2011). Cultures with confluent gill cells were trypsinized (59428C, Sigma) for detachment, counted using a hemocytometer and adjusted to a concentration of $2 \times 10^{5}$ cell $\mathrm{ml}^{-1}$ in L-15 medium. Subsequently, gill cells were seeded in quadruplicate in 96-well flat bottom microplates (3860-096, Iwaki, Japan), using a volume of $100 \mu \mathrm{l}$ per well. After $48 \mathrm{~h}$ at $17^{\circ} \mathrm{C}$ in the dark for gill cell attachment, L-15 medium was discarded, the cells rinsed with PBS and exposed to $100 \mu \mathrm{l}$ 
Pseudochattonella lysed cells and supernatant medium from cultures at 25 and 35 psu at $17^{\circ} \mathrm{C}$ in the dark. A salinity of 25 corresponds to a value measured above the pycnocline during the 2016 El Niño event in the Reloncaví Sound (Clément et al., 2016), and 35 psu is consistent with salinity values measured in the offshore Equatorial Subsurface Water (ESSW) (Silva et al., 1998). Supernatant and lysed cells treatments were prepared from Pseudochattonella cultures in the exponential growth phase at five different concentrations $(10,100,1000,10,000$, and 100,000 cells $\mathrm{ml}^{-1}$ ). The supernatant suspension was prepared by centrifugation of cultures for $5 \mathrm{~min}$ at $3500 \mathrm{rpm}$ and then diluted as needed. The lysed cell suspension was prepared by sonication of diluted samples for $10 \mathrm{~min}$ at an amplitude of $10 \mu \mathrm{m}$ peak to peak at $17^{\circ} \mathrm{C}$ and filtered using a syringe with a nylon filter $(0.22 \mu \mathrm{m})$. After $1 \mathrm{~h}$ exposure, the viability of the gill cells was determined using L-15/ex medium (Schirmer et al., 1997), a modified version of the L-15 medium, containing 5\% of the indicator dye alamarBlue (DAL1025, Invitrogen) (Pagé et al., 1993). The medium containing the indicator dye was added to all cell-seeded wells and incubated for $2 \mathrm{~h}$ in the dark (Dayeh et al., 2005). Using a microplate reader (FLUOstar OMEGA, BMG Labtech), the fluorescence signal of alamarBlue was detected using excitation and emission filters of 540 and $570 \mathrm{~nm}$, respectively. The viability of the gill cells was expressed as response percentage of the treatments relative to the controls (\% of control).

\section{Data Analysis}

To explore the effect of salinity on growth and the ichthyotoxic potency of $P$. verruculosa, analysis of variance (ANOVA) from simple linear regression models on maximum cell density, maximum specific growth rate $\left(\mu_{\max }\right)$ and gill cell viability against Pseudochattonella cell density and intra- and extracellular compounds was performed. Normality and homogeneity of variances were assessed by the Kolmogorov-Smirnov method and Levene's test. A post hoc analysis using a Tukey HSD test was performed to determine differences among treatments. The null hypothesis (no difference in responses) was rejected in all statistical analyses if the respective $p$-value was $<0.05$. These analyses were performed using the software R v. 3.0.1 (Ihaka and Gentleman, $1996^{1}$ ).

\section{RESULTS}

\section{Molecular Identification of Pseudochattonella}

The $250 \mathrm{bp}$ partial LSU rDNA sequence obtained from P. verruculosa ARC498 was identical to six sequences attributed to $P$. verruculosa (AB217643.1, AM850226.1, AM850225.1, AM850224.1, AB217642.1, and AM040504.1), and differed from sequences of Pseudochattonella farcimen by 4-5 substitutions. Phylogenetic trees obtained from these sequences and outgroup rooted with relatives of Pseudochattonella species demonstrate this pattern and give a relative scale of variation between the

\footnotetext{
${ }^{1}$ http://www.r-project.org
}

Chilean strain and other $P$. verruculosa sequences as well as $P$. farcimen. The LSU tree shows the Isla Huar isolate resolved in the $P$. verruculosa clade, although not as a monophyletic group (Figure 2).

\section{Morphological Characteristics and Growth of $P$. verruculosa Cultures}

Cells showed a variable morphology with form and size changing in response to growth phase and salinity treatments. All treatments showed cell shapes ranging from small spherical/oval $(\sim 4-10 \mu \mathrm{m})$ to conical-elongated $(\sim 8-19 \mu \mathrm{m})$. Two heterokont flagella were present. The shortest flagellum faces backward and a longer anteriorly directed flagellum $(\sim 12-22 \mu \mathrm{m})$ pulls the cell forward (Figure 3A). Mucocysts were mainly present in larger than smaller cells. SEM analysis micrographs of the $P$. verruculosa ARC498 cultures (used for the gill cell line assay) showed a more recurrent presence of mucocysts in $P$. verruculosa cells at 25 psu than cells at 35 psu (Figures 3A,B). Mucus secretion was observed to form cell aggregations (Figure 3C).

The response of $P$. verruculosa ARC498 to changes in salinity was significantly different in terms of maximum cell density and maximum specific growth rate $\left(\mu_{\max }\right)$ (ANOVA, df $=4$, $p<0.001$, Figure 4). The highest maximum cell density among all treatments was obtained at salinity 30 (84333 \pm 4833 cells $\left.\mathrm{ml}^{-1}\right)$, and the lowest at salinity $15\left(269 \pm 71\right.$ cells $\left.\mathrm{ml}^{-1}\right)$ (Table 1). The highest $\mu$ max of 1.44 days $^{-1}$ was reached at $20 \mathrm{psu}$ and the lowest at 30 psu with a mean value of 0.88 days $^{-1}$. Multinucleated cell aggregations were observed at the bottom of the flasks throughout the experimental period. After $\sim 15$ days, some cultures exhibited vegetative cell growth that reached modest concentrations under depleted-nutrient conditions (data not shown).

\section{$P$. verruculosa Cytotoxicity Against Fish Gill Cells}

Viability of gill cells after $1 \mathrm{~h}$ exposure to $P$. verruculosa did not show significant differences between the supernatant and ruptured cell treatments (ANOVA, $p>0.05$, Figure 5), and lytic activity showed to slightly increase together with Pseudochattonella cell density at both salinity treatments. Cytotoxicity of intra- and extracellular compounds of $P$. verruculosa did not show significant differences (ANOVA, $p<0.05$; except treatment at 100,000 Pseudochattonella cells $\mathrm{ml}^{-1}$ at 25 psu-day1; Figure 5A) and treatments at salinity 25 showed to be more potent than toxic compounds obtained at salinity 35 , reducing gill cell viability down to $52 \%$ of controls at 100,000 cells $\mathrm{ml}^{-1}$. Lytic compounds of both salinity treatments rapidly degraded in the light conditions, reducing gill cell viability to only less than $20 \%$ after 5 -days storage at $15^{\circ} \mathrm{C}$ (Figure 5).

\section{DISCUSSION}

As $P$. verruculosa is a newly reported species for Chilean waters, almost nothing is known about its ecology. This is the first study to formally confirm the taxonomic identification of Chilean 


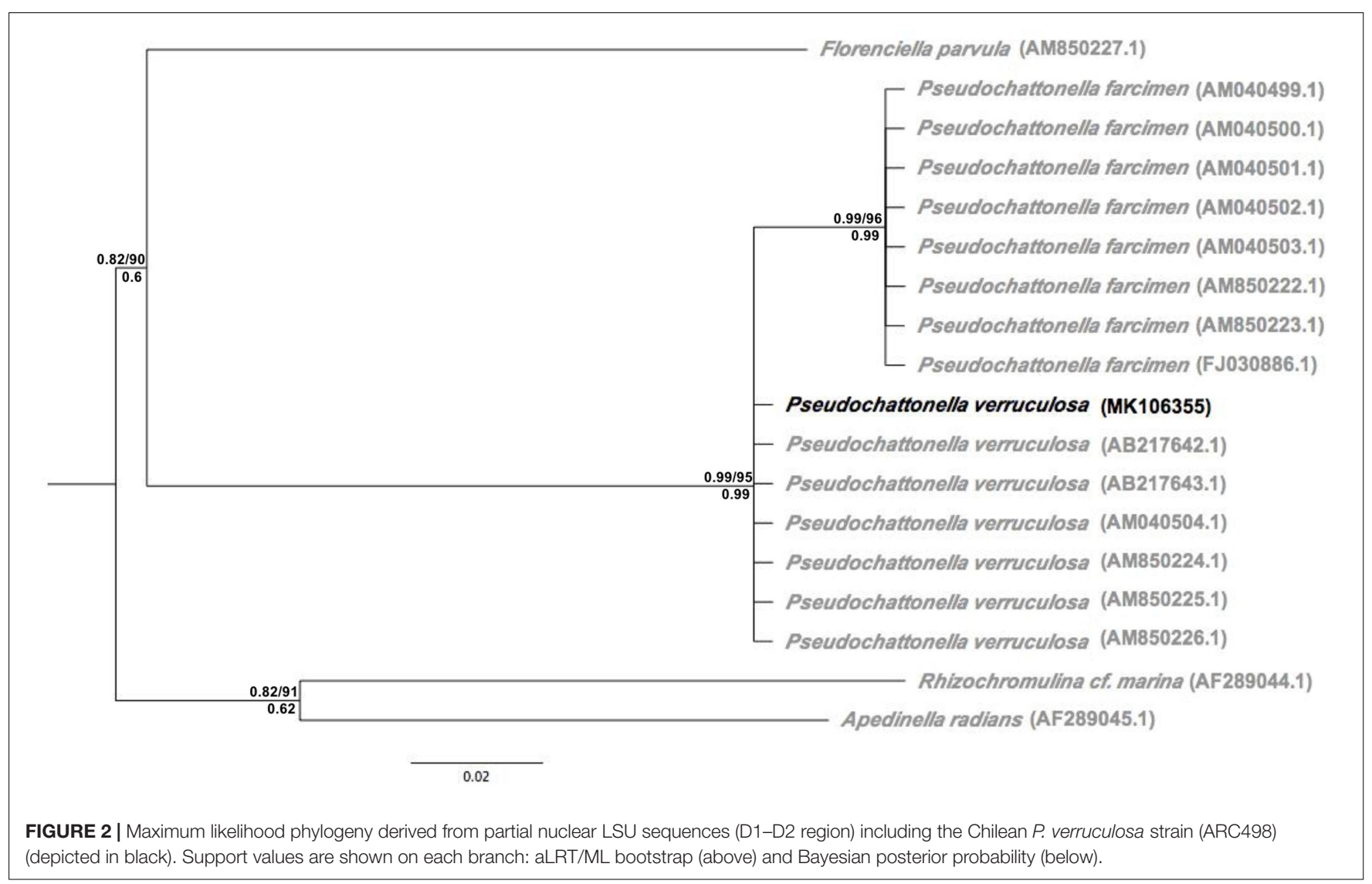

Pseudochattonella populations as $P$. verruculosa using a genetic approach and the first assessment of in vitro cell growth and cytotoxicity.

\section{Molecular Characterization}

To the best of our knowledge, this is the first formal molecular characterization of a Pseudochattonella strain isolated from the massive 2016 bloom in the Reloncaví sound (southern Chile), using a sequence obtained from the LSU rDNA region (Figure 1). These results resolved the Chilean P. verruculosa strain (ARC498) within a clade with others $P$. verruculosa strains from Japan and New Zealand in agreement with Chang et al. (2014) for the same gene. However, other markers (18S, Rbcl, COI, and ITS) should be used to confirm our Chilean Pseudochattonella strain within the $P$. verruculosa clade. This is mainly due to the fact that different gene markers can differ in results. For instance, a Pseudochattonella strain Wellington Harbour (New Zealand) was found to be similar to $P$. verruculosa using the large subunit of ribulose bisphosphate carboxylase ( $\mathrm{rbcL}$ ) and the partial sequences of the nuclear encoded LSU rDNA, whereas sequences of the mitochondrial cytochrome $c$ oxidase subunit (COI) gene grouped this strain as P. farcimen (Chang et al., 2014). Moreover, unpublished sequence data from field samples collected during the 2016 bloom have indicated the potential coexistence of $P$. farcimen blooming together with $P$. verruculosa in the Patagonian fjord area (ADL Diagnostic Chile- personal communication). Under this scenario and given the high morphological variability already described for Pseudochattonella species (Eckford-Soper and Daugbjerg, 2016b), the description of molecular markers becomes a key tool for precise species detection in the Chilean waters. The P. verruculosa ARC498 sequence described in this study has the potential for the design of primers for quantitative PCR (qPCR) aiming a rapid and lowcost identification and quantification tool as used in field samples from Pseudochattonella sp. blooms in Danish waters (EckfordSoper and Daugbjerg, 2016a). In future studies, HPLC pigment analysis could also help for a better Pseudochattonella species discrimination since violaxanthin, lutein, and anteroxanthin are only detected in P. verruculosa (Tomas et al., 2004).

\section{Effect of Salinity on $P$. verruculosa Cultures}

High salinity variations observed in estuarine systems due to water mix or stratification can produce alterations in marine microalgae composition. These effects can include (i) changes in the cellular ionic ratios due to the selective ion permeability of the membrane, (ii) osmotic stress with direct impact on the cellular water potential and (iii) ionic stress caused by the unavoidable uptake or loss of ions (Kirst, 1990). The Reloncaví Sound $\left(41^{\circ} 35^{\prime} \mathrm{S}, 72^{\circ} 20^{\prime} \mathrm{W}\right)$, which is recognized as the 'hot spot' for Pseudochattonella outbreaks in the south of Chile, has a broad range of salinity that can vary from $<10$ psu at the surface to $>30$ psu in deep waters (Castillo et al., 2016). In our study, the P. verruculosa ARC498 strain 

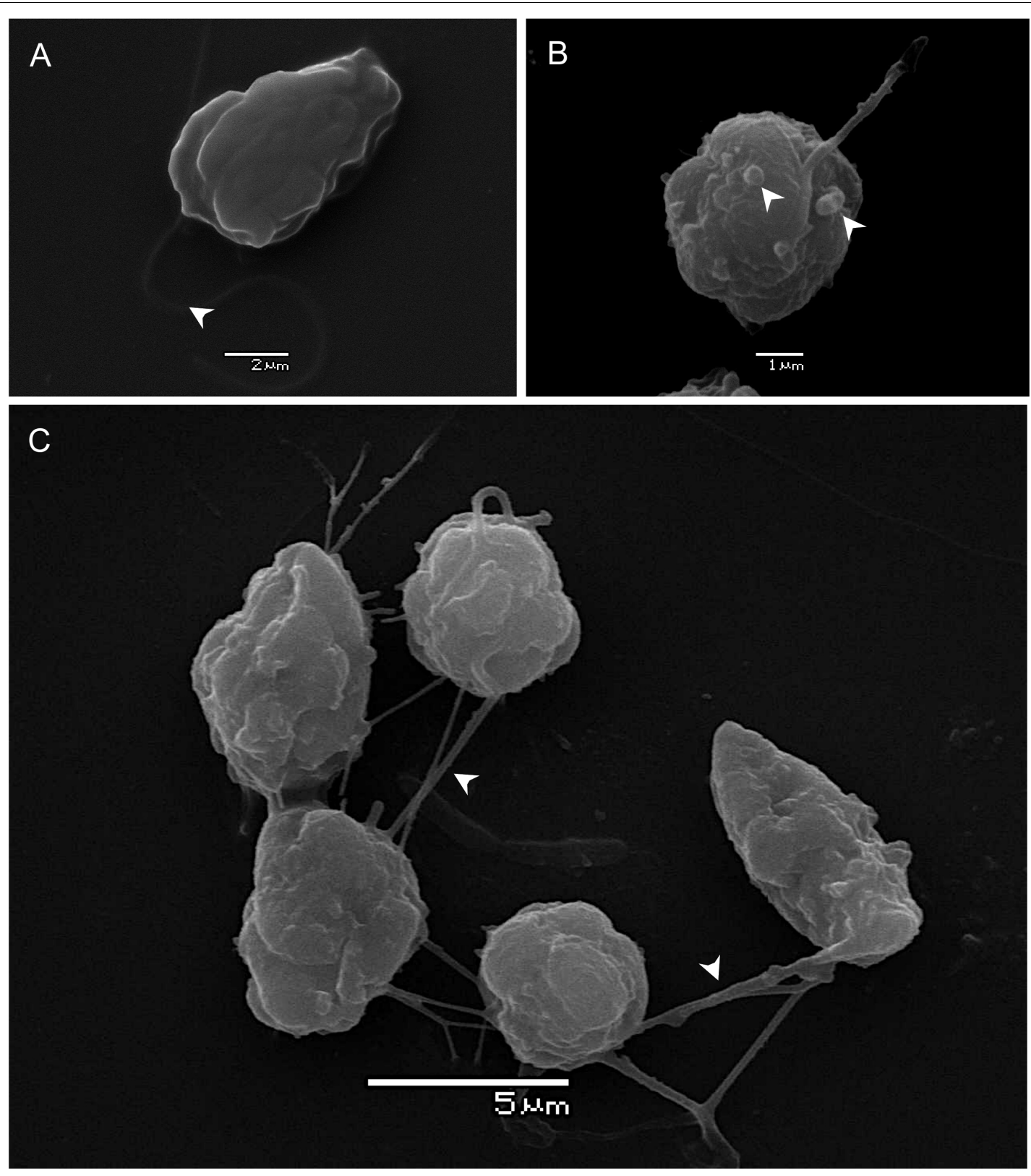

FIGURE 3 | Scanning electron microscopy of $P$. verruculosa ARC498 strain. (A) Ovoid cell with a long forwardly directed flagellum (arrowhead) from culture at 35 in salinity, (B) spherical cell with mucocysts at the periphery of the cell (arrowheads) from culture at 25 in salinity, and (C) group of cells interconnected by thin mucus-filaments (arrowheads).

isolated from the Reloncaví sound reached high cell densities between 20 and 35 psu. At salinity 15, exponential cell growth was 8 days delayed compared to the other salinity treatments and cell densities were several orders of magnitude lower, although positive net growth lasted for several days. These results suggest that freshwater inputs in the upper layer of the fjord may act as an environmental control for P. verruculosa cell growth.

The capacity to maintain high and positive net growth at a broad range of salinity values may have several competitive advantages in a dynamic estuarine system when turbulence breaks the halocline and vertically disperse cell through the water column. This pattern of broad salinity optima has also been observed in the distantly related Dictyocha speculum Ehrenberg (Henriksen et al., 1993). However, it has been suggested that microalgal cell growth primarily depends on temperature and light, with the tolerated salinity range becoming broader as these parameters approach optimality (Kirst, 1990). An increasing tolerance to a high salinity range by our $P$. verruculosa strain could be then a result of in vitro optimal conditions $(20 \mu \mathrm{mol}$ 


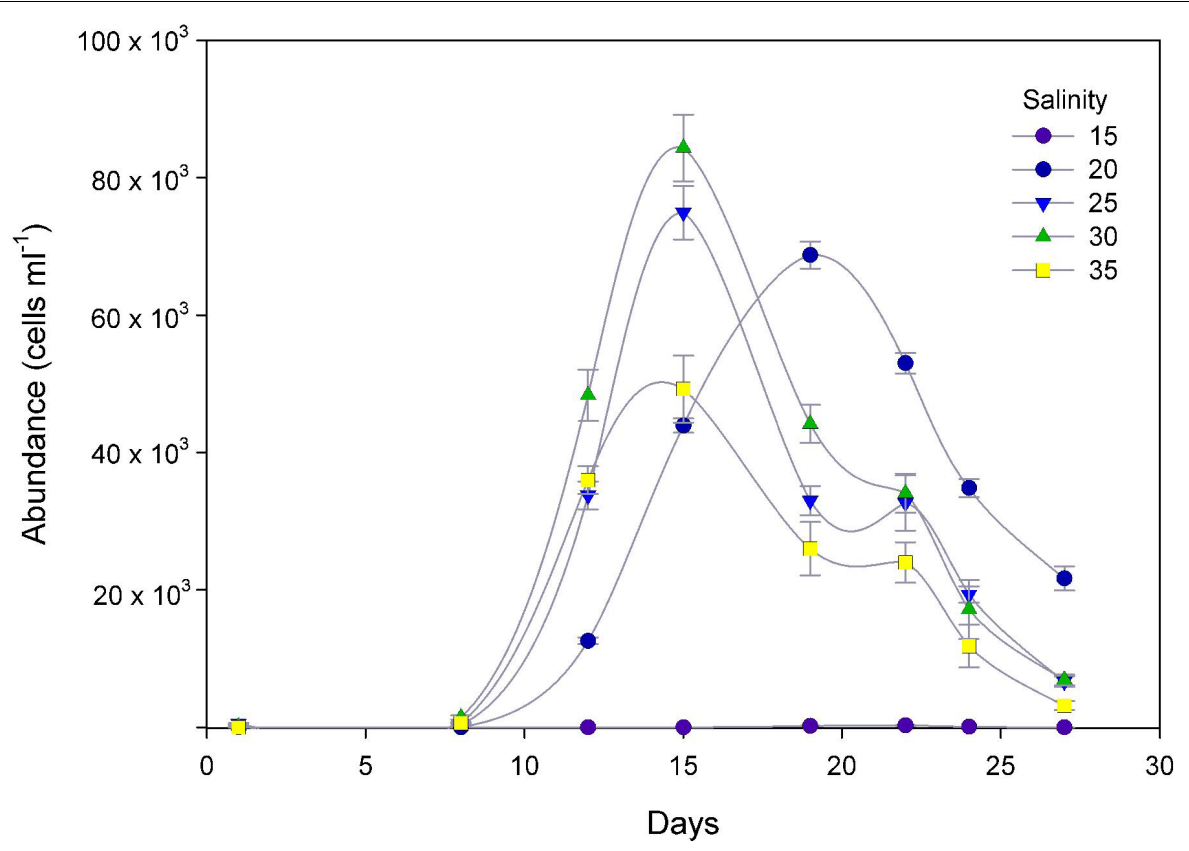

FIGURE 4 | Temporal cell growth curves of $P$. verruculosa cultures under five salinity treatments. Symbols represent the mean and error bars the standard deviation of cell counts from triplicate measurements.

photon $\mathrm{m}^{-2} \mathrm{~s}^{-1}$ and $15^{\circ} \mathrm{C}$ ) and it is likely to change in the highly dynamic fjords. Other aspect to take into account is that the experiments were performed using strains previously acclimated for several generations. Further studies should assess the effect of drastic salinity changes on $P$. verruculosa growth.

In this study, we documented for the first time the cell growth rates for a Chilean $P$. verruculosa strain. Maximum growth rates that ranged between 0.88 to 1.44 days $^{-1}$ were higher compared to those observed by Skjelbred et al. (2013) for Danish $P$. verruculosa strains $\left(0.61\right.$ days $\left.^{-1}\right)$ and lower than 1.74 days $^{-1}$, which was recorded for a Japanese strain (Yamaguchi et al., 1997). The relative high $\mu$ max observed in our experiment could be attributed to a high cell division rate but also to the presence of multinucleated cell aggregations noted at the bottom of our treatment flasks throughout and $\sim 15$ days after the end of the experiment. Similar in vitro cell aggregations have also been observed in other $P$. verruculosa strains from the North Sea and Japan (Tomas et al., 2004). It has been suggested that these massive aggregations could act as resting stages when conditions become unfavorable (Jakobsen et al., 2012; Chang et al., 2014). Thus, in vitro growth rate values could be enhanced by germling cell input from resting stages and also might point to homothallism in our monoclonal ARC498 strain.

\section{Lytic Activity of $\boldsymbol{P}$. verruculosa}

Species of the genus Pseudochattonella has been reported to be highly ichthyotoxic with important economic losses for the Chilean salmon industry since 2004 (Mardones et al., 2012). Most examinations of affected salmon during natural fish-kill events in Chile have shown noticeable edema, hyperplasia and
TABLE 1 | Growth parameters of Pseudochattonella verruculosa cultures (mean $\pm \mathrm{SD}$ ) maximum cell density and $\mu_{\max }$ mean maximum specific growth rate and under five different salinity treatments.

\begin{tabular}{lcc}
\hline Treatment (salinity) & Maximum cell density $\left(\right.$ cells $\left.\mathbf{~ m l}^{-\mathbf{1}}\right)$ & $\boldsymbol{\mu}_{\mathbf{m a x}}\left(\mathbf{d}^{\mathbf{- 1}}\right)$ \\
\hline 15 & $269 \pm 71$ & 1.31 \\
20 & $68750 \pm 1963$ & 1.44 \\
25 & $74916 \pm 3892$ & 1.12 \\
30 & $84333 \pm 4833$ & 0.88 \\
35 & $49250 \pm 4793$ & 1.01 \\
\hline
\end{tabular}

necrosis of secondary gill lamellae (C. Sandoval - VEHICE, personal communication). Despite this, research on the toxic compounds produced by this species is incipient and has proven to be difficult.

The fish cell line RTgill-W1 assay has been widely used to assess cell viability in ichthyotoxic-microalgal studies (Dorantes-Aranda et al., 2015). In this work, we experimentally demonstrated lytic activity of the Chilean P. verruculosa ARC498 strain toward the RTgill-W1 cells, although ecologically realistic $P$. verruculosa bloom concentrations (10,000-100,000 cells $\mathrm{ml}^{-1}$ ) exhibited only very limited loss of viability (down to max. $45 \%$ of controls). These results differ from field observations in the Chilean bloom, where $P$. cf. verruculosa showed to be

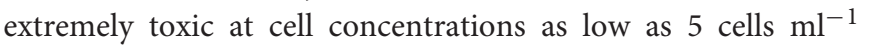
(Mardones et al., 2012). Similarly, Montes et al. (2018), based on Chilean phytoplankton data bases, estimated that $<1$ cell $\mathrm{ml}^{-1}$ can be associated with anomalous salmon behavior in the Patagonian fjords. Comparable to these observations in the Chilean waters, only 10 cells $\mathrm{ml}^{-1}$ of $P$. verruculosa 


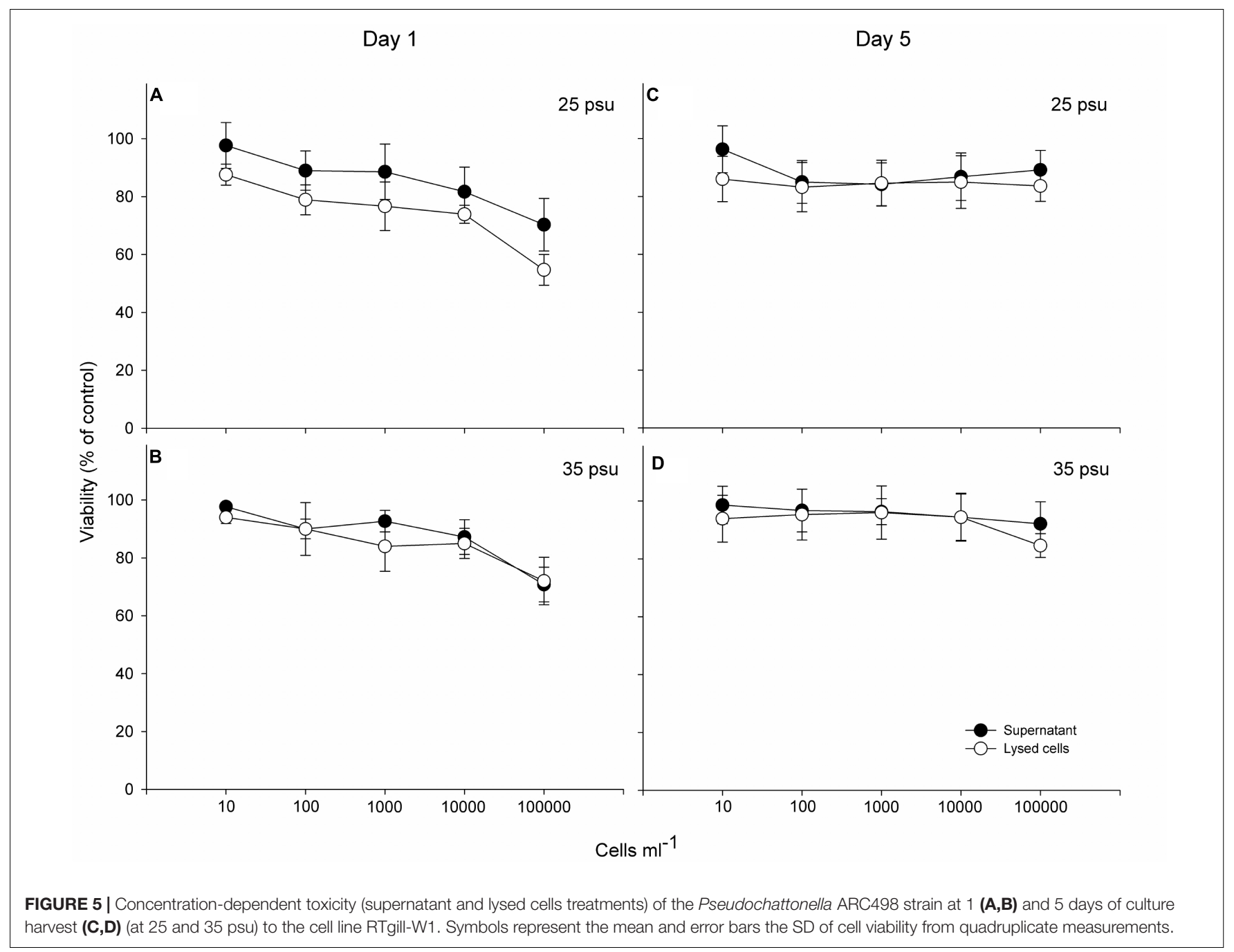

were enough to cause mortality of salmon in New Zealand (MacKenzie et al., 2011). There might be a few experimental conditions that can explain our findings: (1) gill cells were shortly exposed to $P$. verruculosa toxic compounds $(1 \mathrm{~h})$ compared to other studies (Dorantes-Aranda et al., 2015; Mardones et al., 2015). Mardones et al. (2015) showed that some strains of the toxic dinoflagellate Alexandrium catenella were able to reduce gill cell viability down to $20 \%$ of controls at 4,000 cells $\mathrm{ml}^{-1}$ after $2 \mathrm{~h}$ exposure due to net $\mathrm{K}^{+}$efflux from fish gill cells (Mardones et al., 2018). Thus, an increment in the time of exposure to $P$. verruculosa toxic compounds is likely to produce a more severe gill tissue damage; (2) in this study lytic compounds from $P$. verruculosa treatments were tested against the gill cells at 1 and 5 days after their extraction. This storage procedure showed that cytotoxic potency rapidly vanished over a 5-day period. It is likely therefore that P. verruculosa exudates could be more ichthyotoxic as soon as they are released into the surrounding marine environment. This early toxic effect was previously observed in in vitro cytotoxic assays using algal extracts of Pseudochattonella species (Skjelbred et al., 2011); (3) live cells are required to induce a toxic effect on fish as suggested by Andersen et al. (2015); and/or (4) the reduced cytotoxicity observed on gill cells could be merely due to the fact that the ARC498 strain is not highly toxic.

The ichthyotoxic mechanism in Pseudochattonella species is elusive with the mode of action yet to be completely determined (Eckford-Soper and Daugbjerg, 2016b). In this study, cytotoxicity of lysed $P$. verruculosa cells did not show significant differences to that of the supernatant. This suggests that the most lytic portion is released into the cell-free media instead of remaining cell bound. These results might lead to a future explanation of the nature of the toxins produced by Pseudochattonella species and their role in chemical ecology. Initial ideas focused on the concept that phycotoxins acted as defensive chemicals against competitors and predators (Smetacek, 2001). Modern studies suggest that cell bound phycotoxins might play a different ecological function compared to secondary toxic metabolites that are release from the cell to the surrounding environment. Excretion of a toxic compound by individual cells may aim to cease grazing by a motile predator or produce an antibiotic effect to reduce the colonization of microalgal cells by viruses 
or bacteria (Cembella, 2003). For instance, allelochemical activity by the dinoflagellate Alexandrium tamarense against the predatory dinoflagellate Oxyrrhis marina was shown to be unrelated to paralytic shellfish toxins (PST) (Alpermann et al., 2010). Similarly, Mardones et al. (2015, 2018) showed that PST are not involved in fish gill damage, but rather an alternative icthyotoxic mechanism was suggested based on lipid peroxidation products due to a synergistic interaction between Reactive Oxygen Species (ROS) and Polyunsaturated Fatty Acids (PUFA). Interestingly, Pseudochattonella species have shown high proportions of a rare PUFA C1s8:5n-3 and $\mathrm{C} 16: 1 \mathrm{n} 5$ and high ratios of docosahexaenoic acid (DHA) to eicosapentaenoic acid (EPA) (Giner et al., 2008; Dittami and Edvardsen, 2012). This rises a big question about the potential involvement of a PUFA/ROS synergism in the potent ichthyotoxicity observed for the Chilean P. verruculosa ARC498. Key research on PUFAs cell content, as well as, ROS and other active secondary metabolites production for Chilean strains remain to be conducted.

Salinity had a significant effect on $P$. verruculosa ichthyotoxic potency. Cultures at salinity 25 were more toxic than cultures at 35 psu. It was also observed that Pseudochattonella cells at salinity 25 were bigger and showed a higher presence of mucocysts than cells grown at salinity 35 . These mucocysts are present in several species of raphidophytes that have been related to fishkilling events, e.g., Heterosigma akashiwo (Twiner et al., 2005) and Fibrocapsa japonica (Pezzolesi et al., 2010). This suggests the putative involvement of mucocysts to induce a toxic effect on fish gill tissue as suggested by Andersen et al. (2015). However, no experiments to test cytotoxicity with whole cells of Chilean Pseudochattonella have been performed yet.

\section{Ecological Implications}

In this study, changes in salinity were an important driver for in vitro Pseudochattonella cell growth and ichthyotoxic potency. The enhanced cell growth under moderate-high salinity conditions $(\sim 30)$ is in line with field observations during the massive 2016 Pseudochattonella sp. outbreak. The strong El Niño 2015-2016 resulted in an extremely dry summer in the southeast Pacific coast with a record low streamflow and higher than normal solar radiation (León-Muñoz et al., 2018). These extreme meteorological conditions allowed vertical advection of saline and nutrient-rich waters ( $\sim 30 \mathrm{psu})$ that ultimately resulted in an enhanced Pseudochattonella sp. bloom that reached peak cell densities of $\sim 7,700$ to 20,000 cells $\mathrm{ml}^{-1}$ (Clément et al., 2016; León-Muñoz et al., 2018). Thus, the lower Pseudochattonella cell concentrations recorded in the 2005, 2009, and 2011 outbreaks could have been the result of highly stratified water columns with higher freshwater inputs in the surface. However, those low-cell density outbreaks produced substantial fish gill damage with less than 20 cells $\mathrm{ml}^{-1}$, suggesting the important effect of moderate-lower salinity on the enhanced ichthyotoxic potency ( 20-25 psu).

Although the macro-scale El Niño 2015-2016 event produced evident changes in the haline structure of the water column in the Reloncaví Sound, it is important to highlight that $p \mathrm{CO}_{2} / \mathrm{pH}$ and nutrient composition/availability, among other variables, should also have been affected. Mardones et al. (2016) showed that spatio-temporal $p \mathrm{CO}_{2} / \mathrm{pH}$ fluctuations in Chilean fjords can strongly affect physiological responses in A. catenella. Physiological changes such as reduced cell size and enhanced chain formation at high $\mathrm{pH} /$ low $\mathrm{pCO}_{2}$ (i.e., phytoplankton bloom conditions) were observed. On the other hand, the entry of offshore waters rich in inorganic nutrients (i.e., $\mathrm{NO}_{3}{ }^{-}$) vs. inland waters, highly influenced by organic nutrients (i.e., $\mathrm{NH}_{4}{ }^{+}$) due to intense aquaculture, might have contributed to changes in phytoplankton community composition by differences in $\mathrm{NH}_{4}{ }^{+}$ and $\mathrm{NO}_{3}{ }^{-}$taxon-specific metabolism. The role of these key chemical variables in the bloom dynamics of Pseudochattonella species should be pursued in future experiments.

Finally, the extremely high cell densities obtained in our in vitro experiments $\left(>80,000\right.$ cells $\left.\mathrm{ml}^{-1}\right)$ compared to field counts, may reflect the difficulty in the Pseudochattonella sp. cell identification using light microscopy. The complex life cycle of Pseudochattonella species, that also includes very small flagellate and large multinucleated stages (Chang et al., 2014; this study), likely lead to misidentification and cell count sub-estimations of the 2016 Pseudochattonella sp. outbreak. Therefore, the advent of molecular approaches becomes an important tool for improving the effectiveness of monitoring programs.

In conclusion, the present work has formally confirmed the presence of $P$. verruculosa in Chilean waters, as well as, showed the effect of salinity on cell growth and ichthyotoxic potency. Overall, high growth rates observed at moderatehigh salinity might help to explain the massive outbreak recorded in 2016. The increasing cytotoxicity by $P$. verruculosa under low-salinity conditions may be important to understand fish-killing properties of the Chilean strains since blooms of this dictyochophyte occur in highly variable oceanographic conditions, such as those occurring in the southern Chilean coast. The role of mucocysts, as well as, production of PUFAs, ROS and/or secondary metabolites that could explain ichthyotoxicity by Chilean strains of $P$. verruculosa remain to be investigated.

\section{AUTHOR CONTRIBUTIONS}

All authors conceived, designed, and performed the experiments and analysis. JM analyzed the data and wrote the manuscript with contributions from all authors.

\section{FUNDING}

Funding was provided by the "Instituto de Fomento PesqueroIFOP” (Grants: MR 656-103 and CORFO 480-018) and UNCW's Marine Biotechnology Program (MARBIONC) funded by the State of North Carolina (United States).

\section{ACKNOWLEDGMENTS}

We thank Pamela Carbonell, Bianca Olivares, and Marco Pinto for technical assistance. 


\section{REFERENCES}

Alpermann, T. J., Tillmann, U., Beszteri, B., Cembella, A. D., and John, U. (2010). Phenotypic variation and genotypic diversity in a planktonic population of the toxigenic marine dinoflagellate Alexandrium tamarense (Dinophyceae). J. Phycol. 46, 18-32. doi: 10.1111/j.1529-8817.2009.00767.x

Alves-de-Souza, C., Varela, D., Contreras, C., de La Iglesia, P., Fernández, P., Hipp, B., et al. (2014). Seasonal variability of Dinophysis spp. and Protoceratium reticulatum associated to lipophilic shellfish toxins in a strongly stratified Chilean fjord. Deep Sea Res. II 101, 152-162. doi: 10.1016/j.dsr2.2013.01.014

Andersen, N. G., Hansen, P. J., Engell-Sørensen, K., Nørremark, L. H., Andersen, P., Lorenzen, E., et al. (2015). Ichthyotoxicity of the microalga Pseudochattonella farcimen under laboratory and field conditions in Danish waters. Dis. Aquat. Organ. 116, 165-172. doi: 10.3354/dao02916

Anisimova, M., and Gascuel, O. (2006). Approximate likelihood-ratio test for branches: a fast, accurate, and powerful alternative. Syst. Biol. 55, 539-552. doi: 10.1080/10635150600755453

Baba, T., Momoyama, K., and Hiraoka, M. (1995). A harmful flagellate plankton increased in Tokuyama Bay. Bull. Yamaguchi Prefect. Naikai Fish. Exp. Stn. 24, $121-122$.

Bols, N. C., Barlian, A., Chirino-Trejo, M., Caldwell, S. J., Goegan, P., and Lee, L. E. J. (1994). Development of a cell line from primary cultures of rainbow trout, Oncorhynchus mykiss (Walbaum), gills. J. Fish. Dis. 17, 601-611. doi: 10.1111/j.1365-2761.1994.tb00258.x

Botes, L., Price, B., Waldron, M., and Pitcher, G. C. (2002). A simple and rapid scanning electron microscope preparative technique for delicate "Gymnodiniod" dinoflagellates. Microsc. Res. Tech. 59, 128-130. doi: 10.1002/ jemt.10184

Castillo, M. I., Cifuentes, U., Pizarro, O., Djurfeldt, L., and Cáceres, M. (2016). Seasonal hydrography and surface outflow in a fjord with a deep sill: the Reloncaví fjord. Chile Ocean Sci. 12, 533-544. doi: 10.5194/os-12-533-2016

Cembella, A. (2003). Chemical ecology of eukaryotic microalgae in marine ecosystems. Phycologia 42, 420-447. doi: 10.2216/i0031-8884-42-4-420.1

Chang, F. H., Sutherland, J. E., McVeagh, M., and Gall, M. (2014). Molecular phylogeny, pigment composition, toxicology and life history of Pseudochattonella cf. verruculosa (class Dictyochophyceae) from Wellington harbour, New Zealand. Harmful Algae 34, 42-55. doi: 10.1016/j.hal.2014. 02.002

Clément, A., Lincoquero, L., Saldivia, M., Brito, C. G., Muñoz, F., Fernández, C., et al. (2016). Exceptional summer conditions and HABs of Pseudochattonella in Southern Chile create record impacts on salmon farms. Harmful Algal News 53, $1-3$.

Dayeh, V. R., Schirmer, K., Lee, L. E. J., and Bols, N. C. (2005). "Rainbow trout gill cell line microplate cytotoxicity test," in Small-Scale Freshwater Toxicity Investigations, eds C. Blaise and J. F. Férard (Berlin: Springer), 473-503. doi: 10.1007/1-4020-3120-3_16

Dittami, S. M., and Edvardsen, B. (2012). Culture conditions influence cellular RNA content in ichthyotoxic flagellates of the genus Pseudochattonella (Dictyochophyceae). J. Phycol. 48, 1050-1055. doi: 10.1111/j.1529-8817.2012. 01183.x

Dorantes-Aranda, J. J., Seger, A., Mardones, J. I., Nichols, P. D., and Hallegraeff, G. M. (2015). Progress in understanding algal bloom-mediated fish kills: the role of superoxide radicals, phycotoxins and fatty acids. PLoS One 10:e133549. doi: 10.1371/journal.pone.0133549

Dorantes-Aranda, J. J., Waite, T. D., Godrant, A., Rose, A., Tovar, C. D., Woods, G. M., et al. (2011). Novel application of a fish gill cell line assay to assess ichthyotoxicity of harmful marine microalgae. Harmful Algae 10, 366-373. doi: 10.1016/j.hal.2011.01.002

Eckford-Soper, L. K., and Daugbjerg, N. (2016a). A quantitative real-time PCR assay for identification and enumeration of the occasionally cooccurring ichthyotoxic Pseudochattonella farcimen and $P$. verruculosa (Dictyochophyceae) and analysis of variation in gene copy numbers during the growth phase of single and mixed cultures. J. Phycol. 52, 174-183. doi: $10.1111 /$ jpy.12389

Eckford-Soper, L. K., and Daugbjerg, N. (2016b). The ichthyotoxic genus Pseudochattonella (Dictyochophyceae): distribution, toxicity, enumeration, ecological impact, succession and life history - A review. Harmful Algae 58, 51-58. doi: 10.1016/j.hal.2016.08.002
Edgar, R. C. (2004). MUSCLE: multiple sequence alignment with high accuracy and high throughput. Nucleic Acids Res. 32, 1792-1797. doi: 10.1093/nar/gk h340

Edvardsen, B., Eikrem, W., Shalchian-Tabrizi, K., Riisberg, I., Johnsen, G., Naustvoll, L., et al. (2007). Verrucophora farcimen gen. et sp. nov. (Dictyochophyceae, Heterokonta) - a bloom-forming ichthyotoxic flagellate from the Skagerrak, Norway. J. Phycol. 43, 1054-1070. doi: 10.1111/j.1529-8817. 2007.00390.x

Edvardsen, B., Shalchian-Tabrizi, K., Jakobsen, K. S., Medlin, L. K., Dahl, E., Brubak, S., et al. (2003). Genetic variability and molecular phylogeny of Dinophysis species (Dinophyceae) from Norwegian waters inferred from single cell analyses of rDNA. J. Phycol. 39, 395-408. doi: 10.1046/j.1529-8817.2003. 01252.x

Eikrem, W., Edvardsen, B., and Throndsen, J. (2009). Renaming Verrucophora farcimen Eikrem, Edvardsen et Throndsen. Phycol. Res. 57:170. doi: 10.1111/ j.1440-1835.2009.00535.x

Giner, J.-L., Zhao, H., and Tomas, C. (2008). Sterols and fatty acids of three harmful algae previously assigned as Chattonella. Phytochemistry 69, 2167-2171. doi: 10.1016/j.phytochem.2008.05.013

Guillard, R. R., and Ryther, J. H. (1962). Studies of marine planktonic diatoms. I. Cyclotella nana Hustedt, and Detonula confervacea (cleve) Gran. Can. J. Microbiol. 8, 229-239. doi: 10.1139/m62-029

Guindon, S., Dufayard, J. F., Lefort, V., Anisimova, M., Hordijk, W., and Gascuel, O. (2010). New algorithms and methods to estimate maximumlikelihood phylogenies: assessing the performance of PhyML 3.0. Syst. Biol. 59, 307-321. doi: 10.1093/sysbio/syq010

Hallegraeff, G. M. (2003). "Harmful algal blooms: a global overview," in Manual on Harmful Marine Algae, eds G. M. Hallegraeff, D. M. Anderson, and A. D. Cembella (Paris: UNESCO), 25-49.

Hallegraeff, G. M., Dorantes-Aranda, J. J., Mardones, J. I., and Seger, A. (2017). "Review of progress in our understanding of fish-killing microalgae: implications for management and mitigation," in Marine and Fresh-water Harmful Algae. Proceedings of the 17th International Conference on Harmful Algae, eds L. A. O. Proença and G. M. Hallegraeff (Paris: International Society for the Study of Harmful Algae and Intergovernmental Oceanographic Commission of UNESCO), 148-153.

Hara, Y., Doi, K., and Chihara, M. (1994). Four new species of Chattonella (Raphidophyceae, Chromophyta) from Japan. Jpn. J. Phycol. 42, 407-420.

Henriksen, P., Knipschildt, F., Moestrup, Ø., and Thomsen, H. A. (1993). Autecology, life history and toxicology of the silicoflagellate Dictyocha speculum (Silicoflagellata, Dictyochophyceae). Phycologia 32, 29-39. doi: 10.2216/i00318884-32-1-29.1

Holliday, D. V., Donaghay, P. L., Greenlaw, C. F., McGehee, D. E., McManus, M. A., Sullivan, J. M., et al. (2003). Advances in defining fine- and micro-scale pattern in marine plankton. Aquat. Living Res. 16, 131-136. doi: 10.1016/S09907440(03)00023-8

Hosoi-Tanabe, S., Honda, D., Fukaya, S., Otake, I., Inagaki, Y., and Sako, Y. (2007). Proposal of Pseudochattonella verruculosa gen. nov., comb. nov. (Dictyochophyceae) for a formal raphidophycean alga Chattonella verruculosa, based on 18S rDNA phy- logeny and ultrastructural characteristics. Phycol. Res. 55, 185-192. doi: 10.1111/j.1440-1835.2007.00461.x

Ihaka, R., and Gentleman, R. (1996). A language for data analysis and graphics. J. Comput. Graph. Stat. 5, 299-314.

Imai, I., Yamaguchi, M., and Watanabe, M. (1998). "Ecophysiology, life cycle and bloom dynamics of Chattonella in the Seto Inland Sea, Japan," in Physiological Ecology of Harmful Algal Blooms, eds D. M. Anderson, A. Cembella, and G. Hallegraeff (Berlin: Springer), 95-112.

Jakobsen, R., Hansen, P. J., Daugbjerg, N., and Andersen, N. G., (2012). The fish-killing dictyochophyte Pseudochattonella farcimen: adaptations leading to bloom formation during early spring in Scandinavian waters. Harmful Algae 18, 84-95. doi: 10.1016/j.hal.2012.04.008

Jeong, H. J., Seong, K. A., Kang, N. S., Yoo, Y. D., Nam, S. W., Park, J. Y., et al. (2010). Feeding by raphidophytes on the cyanobacterium Synechococcus sp. Aquat. Microb. Ecol. 58, 181-195. doi: 10.3354/ame0 1354

Kirst, G. O. (1990). Salinity tolerance of eukaryotic marine algae. Annu. Rev. Plant. Phys. 41, 21-53. doi: 10.1093/gbe/evw152 
León-Muñoz, J., Urbina, M. A., Garreaud, R., and Iriarte, J. L. (2018). Hydroclimatic conditions trigger record harmful algal bloom in western Patagonia (summer 2016). Sci. Rep. 8:1330. doi: 10.1038/s41598-018-19461-4

Lu, D., and Goebel, J. (2000). Chattonella sp. bloom in North Sea, spring 2000. Harmful Algae News 21, 10-11.

MacKenzie, L. A., Smith, K. F., Rhodes, L. L., Brown, A., Langi, V., Edgar, M., et al. (2011). Mortalities of sea-cage salmon (Oncorhynchus tshawytscha) due to a bloom of Pseudochattonella verruculosa (Dictyochophyceae) in Queen Charlotte Sound, New Zealand. Harmful Algae 11, 45-53. doi: 10.1016/j.hal. 2011.07.003

Mardones, J., Clément, A., and Rojas, X. (2012). Monitoring potentially ichthyotoxic phytoflagellates in the southern fjords of Chile. Harmful Algae News 45, 6-7.

Mardones, J. I., Dorantes-Aranda, J. J., Nichols, P. D., and Hallegraeff, G. M. (2015). Fish gill damage by the dinoflagellate Alexandrium catenella from Chilean fjords: synergistic action of ROS and PUFA. Harmful Algae 49, 40-49. doi: 10.1016/j.hal.2015.09.001

Mardones, J. I., Müller, M. N., and Hallegraeff, G. M. (2016). Toxic dinoflagellate blooms of Alexandrium catenella in Chilean fjords: a resilient winner from climate change. ICES J. Mar. Sci. 74, 988-995. doi: 10.1093/icesjms/fsw164

Mardones, J. I., Shabala, L., Shabala, S., Dorantes-Aranda, J. J., Seger, A., and Hallegraeff, G. M. (2018). Fish gill damage by harmful microalgae newly explored by microelectrode ion flux estimation techniques. Harmful Algae 80, 55-63. doi: 10.1016/j.hal.2018.09.004

Montes, R. M., Rojas, X., Artacho, P., Tello, A., and Quiñones, R. A. (2018). Quantifying harmful algal bloom thresholds for farmed salmon in southern Chile. Harmful Algae 77, 55-65. doi: 10.1016/j.hal.2018.05.004

Naustvoll, L., Dahl, E., Danielssen, D., Aure, J., Skogen, M., and Budgell, P. (2002). Chattonella i Skagerrak - en ny trussel for oppdrettsnæringen? Havets Miljø, Fisk. Havet Sornummer 2, 126-129.

Pagé, B., Pagé, M., and Noël, C. (1993). A new fluorometric assay for cytotoxicity measurements in vitro. Int. J. Oncol. 3, 473-476. doi: 10.3892/ijo.3.3.473

Paredes, J., Aguilera, A., Olivares, B., Uribe, C., Urrutia, G., Seguel, M., et al. (2016). "Morphological variability and genetic identification of ichthyotoxic species Pseudochattonella sp. isolated from severe outbreak in 2016 at the northern Patagonian Fjord, southern Chile," in Poster Presentation at the 17th International Conference on Harmful Algae, Florianópolis.

Pezzolesi, L., Cucchiari, E., Guerrini, F., Pasteris, A., Galletti, P., Tagliavini, E., et al. (2010). Toxicity evaluation of Fibrocapsa japonica from the Northern Adriatic Sea through a chemical and toxicological approach. Harmful Algae 9, 504-514. doi: 10.1016/j.hal.2010.03.006

Posada, D. (2008). jModelTest: phylogenetic model averaging. Mol. Biol. Evol. 25, 1253-1256. doi: 10.1093/molbev/msn083

Rignot, E., Rivera, A., and Casassa, G. (2003). Contribution of the Patagonia Icefields of South America to sea level rise. Science 302, 434-437. doi: 10.1126/ science. 1087393

Riisberg, I., and Edvardsen, B. (2008). Genetic variation in bloom-forming ichthyotoxic Pseudochattonella species (Dictyochophyceae, Heterokonta) using nuclear, mitochondrial and plastid DNA sequence data. Eur. J. Phycol. 43, 413-422. doi: 10.1080/09670260802299602

Ronquist, F., and Huelsenbeck, J. P. (2003). MRBAYES 3: Bayesian phylogenetic inference under mixed models. Bioinformatics 19, 1572-1574. doi: 10.1093/ bioinformatics/btg180

Schirmer, K., Chan, A. G. J., Greenberg, B. M., Dixon, D. G., and Bols, N. C. (1997). Methodology for demonstrating and measuring the photocytotoxicity of fluoranthene to fish cells in culture. Toxicol. In Vitro 11, 107-119. doi: 10.1016/S0887-2333(97)00002-7

Scholin, C. A., Herzog, M., and Anderson, D. M. (1994). Identification of group and strain specific genetic markets for globally distributed Alexandrium
(Dinophyceae). II. Sequence analysis of a fragment of the LSU rRNA gene. J. Phycol. 30, 999-1011. doi: 10.1111/j.0022-3646.1994.00999.x

Silva, N., Calvete, C., and Sievers, H. (1998). Masas de agua y circulación general para algunos canales australes Chilenos entre Puerto Montt y Laguna San Rafael (Crucero CIMAR-Fiordo 1). Cienc. Tecnol. Mar. 21, 17-48.

Skjelbred, B., Edvardsen, B., and Andersen, T. (2013). Environmental optima for seven strains of Pseudochattonella (Dictyochophyceae, Heterokonta). J. Phycol. 49, 54-60. doi: 10.1111/jpy.12008

Skjelbred, B., Horsberg, T. E., Tollefsen, K. E., Andersen, T., and Edvardsen, B. (2011). Toxicity of the ichthyotoxic marine flagellate Pseudochattonella (Dictyochophyceae, Heterokonta) assessed by six bioassays. Harmful Algae 10, 144-154. doi: 10.1016/j.hal.2010.08.007

Smetacek, V. (2001). A watery arms race. Nature 411:745. doi: 10.1038/35081210

Stacey, M. T., McManus, M. M., and Steinbuck, J. V. (2007). Convergences and divergences and thin layer formation and maintenance. Limnol. Oceanogr. 52, 1523-1532. doi: 10.4319/lo.2007.52.4.1523

Sullivan, J. M., McManus, M. A., Cheriton, O. M., Benoit-Bird, K. J., Goodman, L., Wang, Z., et al. (2010). Layered organization in the Coastal Ocean: an introduction to thin layers and the LOCO project. Cont. Shelf Res. 30, 1-6. doi: 10.1016/j.csr.2009.09.001

Tillmann, U., and Reckermann, M. (2002). Dinoflagellate grazing on the raphidophyte Fibrocapsa japonica. Aquat. Microb. Ecol. 26, 247-257. doi: 10. 3354/ame026247

Tomas, C. R., Ono, C., Yoshimatsu, S., and Gobel, J. (2004). "Chattonella verruculosa and related species from Japan, Europe (North Sea) and U.S. coastal waters: cases of mistaken identity?," in Harmful Algae, eds K. A. Steidinger, J. H. Landsberg, C. R. Tomas, and G. A. Vargo (Tallahassee: Florida Fish and Wildlife Conservation Commission), 425-427.

Twiner, M. J., Chidiac, P., Dixon, S. J., and Trick, C. G. (2005). Extracellular organic compounds from the ichthyotoxic red tide alga Heterosigma akashiwo elevate cytosolic calcium and induce apoptosis in Sf9 cells. Harmful Algae 4, 789-800. doi: 10.1016/j.hal.2004.12.006

Wright, J. L. C., and Cembella, A. D. (1998). "Ecophysiology and biosynthesis of polyether marine biotoxins," in Physiological Ecology of Harmful Algae Blooms, eds D. M. Anderson, A. D. Cembella, and G. M. Hallegraeff (Berlin,: Springer), 427-451.

Yamaguchi, M., Itakura, S., Nagasaki, K., Matsuyama, Y., Uchida, T., and Imai, I. (1997). Effects of temperature and salinity on the growth of the red tide flagellates Heterocapsa circularisquama (Dinophyceae) and Chattonella verruculosa (Raphidophyceae). J. Plankton Res. 19, 1167-1174. doi: 10.1093/ plankt/19.8.1167

Yamamoto, C., and Tanaka, Y. (1990). Two species of harmful red tide plankton increased in Fukuoka Bay. Bull. Fukuoka Fish. Exp. Stn. 16, 43-44.

Yamazaki, H., Honma, H., Nagai, T., Doubell, M., Amakasu, K., and Kumagai, M. (2010). Multilayer biological structure and mixing in the upper water column of Lake Biwa during summer 2008. Limnology 11, 63-70. doi: 10.1007/s10201009-0288-2

Conflict of Interest Statement: The authors declare that the research was conducted in the absence of any commercial or financial relationships that could be construed as a potential conflict of interest.

Copyright (c) 2019 Mardones, Fuenzalida, Zenteno, Alves-de-Souza, Astuya and Dorantes-Aranda. This is an open-access article distributed under the terms of the Creative Commons Attribution License (CC BY). The use, distribution or reproduction in other forums is permitted, provided the original author(s) and the copyright owner(s) are credited and that the original publication in this journal is cited, in accordance with accepted academic practice. No use, distribution or reproduction is permitted which does not comply with these terms. 